\title{
Revisiting human-environment interactions in Chaco Canyon and the American Southwest
}

\author{
Julio L. Betancourt ${ }^{1}$ and Christopher H. Guiterman ${ }^{2}$
}

\begin{abstract}
Chaco Canyon was the center of a regionally integrated system. Despite a century of research, questions remain about its rise and fall, and the role of human-environment interactions. The answers may lie in current events and new tools and perspectives.
\end{abstract}

Chaco Canyon in northwestern New Mexico, USA, boasts a spectacular array of prehistoric ruins, meriting status as a US National Historical Park and UNESCO World Heritage Site. First excavated 120 years ago, Chaco Canyon may be the most-studied archaeological site in the USA, motivating hundreds of publications and even its own queryable archive and database (www.chacoarchive.org/ cra/). The desolate canyon, a marginal and unpredictable environment, supported the Ancient Puebloans in developing a complex society and regionally integrated system that, at its nadir in the 11th century, was centered on Chaco and spanned $>50,000 \mathrm{~km}^{2}$ (Fig. 1). In popular literature, Chaco's genesis inspires awe - "a dazzling show of wealth and power in a treeless desert" (FernándezArmesto 2001) - while its collapse stirs deep reflection about "environmental impact and climate change intersecting" (Diamond 2005).

Despite more than a century of focused research, there are still many unanswered questions (e.g. Plog and Heitman 2010). The Chaco Phenomenon emerged quickly AD 850 from dispersed rural communities subsisting on maize, beans and squash, flourished for a few centuries, then collapsed between AD 1130 and 1150. In its heyday, the Chaco Phenomenon was distinguished by planned architecture of multistoried great houses; shared ceramic traditions and rituals; intensive agriculture and sophisticated water-control features; long-distance trade of luxury items (cacao, macaw and parrot feathers, copper bells, turquoise, and seashells); and an extensive network of well-constructed roads.

\section{Integrating a regional human- environmental system}

Today, Chaco is deficient in natural resources (Fig. 1), giving rise to the idea that Chaco Society was a regionally integrated system that relied on resource-rich areas and outlying communities. Chaco could have acted as a center for storage and redistribution of surplus food, particularly maize, by a small and elite population housed in the canyon, or as a religious center into which food and other goods flowed during pilgrimages that reinforced system-wide religious authority. Others counter that Chaco looked very different 1,000 years ago, and was a productive agricultural center able to sustain a large population throughout most of its three-century tenure. These differing perspectives on the Canyon's environment and its social structure lead to widely ranging population estimates during the Chaco Phenomenon from $<10,000$ to $>100,000$ people (Minnis 2015).

\section{Timber and fuel for great houses}

The Ancient Puebloans at Chaco quarried sandstone blocks and logged hundreds of thousands of trees, mostly big conifers that do not grow locally today, to build the dozen or more great houses, considered the largest buildings in North America north of Mexico until the 19th century. Plant macrofossils from packrat middens on the canyon slopes showed that ponderosa pine (Pinus ponderosa), the main architectural timber, grew locally only as scattered individuals during the late Holocene - not enough to sustain architectural needs (Betancourt and Van Devender 1981). Engelmann spruce (Picea engelmannii) and subalpine fir (probably Abies lasiocarpa), which made up a quarter of the architectural wood (Betancourt et al. 1986), last grew in the canyon 12,000 years ago, and must have been logged from mountaintops $>75 \mathrm{~km}$ away. Tree-growth patterns show that, prior to AD 1020, nearly all of the timber was procured from the Zuni Mountains $>80 \mathrm{~km}$ to the southwest
(Guiterman et al. 2016). Later during the mid-11th century Chacoan fluorescence, both tree-growth patterns and strontium isotopes indicate that most of the timber came from the Chuska Mountains $>75 \mathrm{~km}$ to the west (English et al. 2001; Reynolds et al. 2005; Guiterman et al. 2016). This shift in tree sources is associated with nearly two decades of drought conditions in the Zunis that were apparently less marked in the Chuskas (Fig. 2). Along with timber, the Chuskas were a major source for stone tools, pottery and maize. The area also emerges as a primary resource for deer, rabbits and prairie dogs consumed at Chaco (Grimstead et al. 2016).

While timber and other resources were clearly procured from long distances, fuelwood was available locally. The packrat midden record shows persistent and ubiquitous pinyon pine throughout the late Holocene until it was locally extirpated between AD 700 and 1500. To this day, pinyon populations show no sign of recovery. So the question is not just what caused pinyon's extirpation, but also what has prevented its recovery? The explanation could well involve climate or woodcutting. Under a woodcutting scenario (Samuels and Betancourt 1982), Chacoans could have easily wiped out the woodland in a couple centuries, likely pushing firewood gathering to more distant

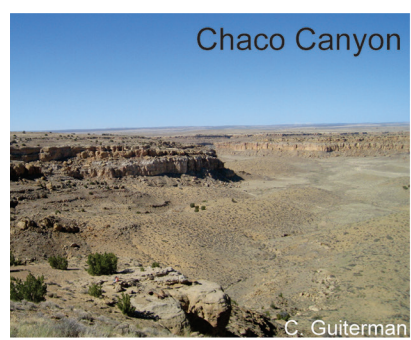

Chuska Mountains
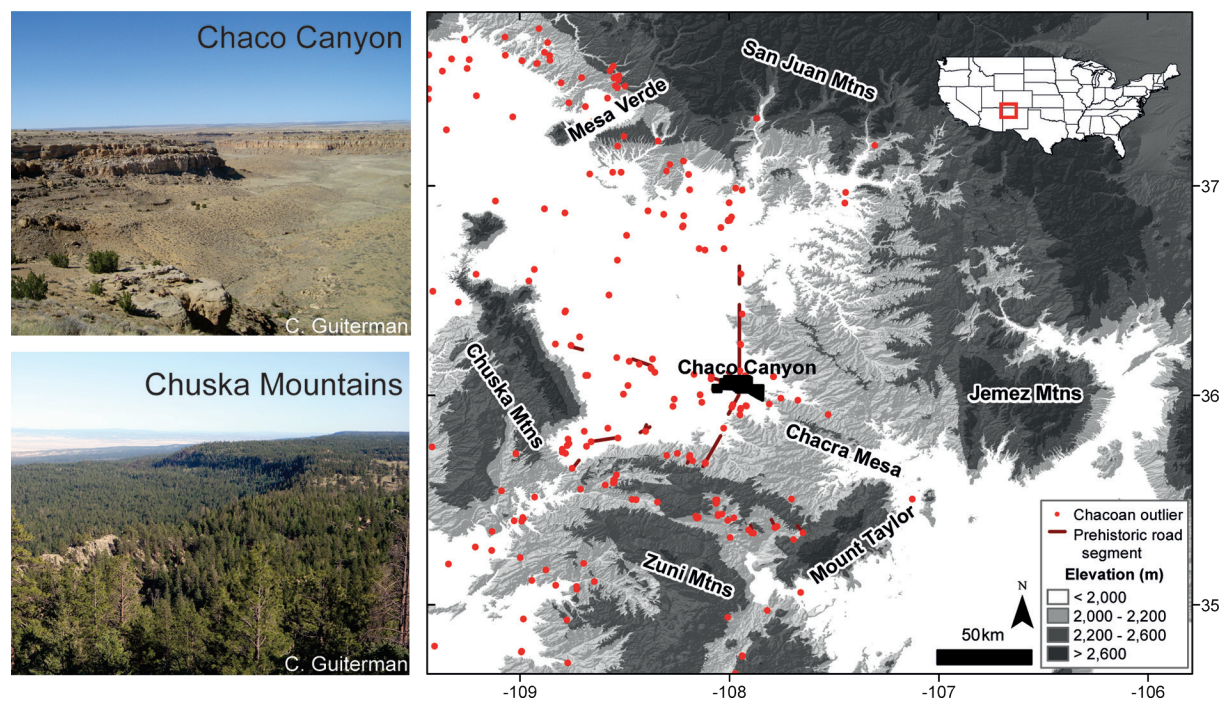

Figure 1: The regional system centered on Chaco Canyon, but associated "outlier" communities populated the western half of the San Juan Basin. Distant areas like the Chuska Mountains were far richer in timber and other resources than Chaco Canyon at the time, as they are now. 


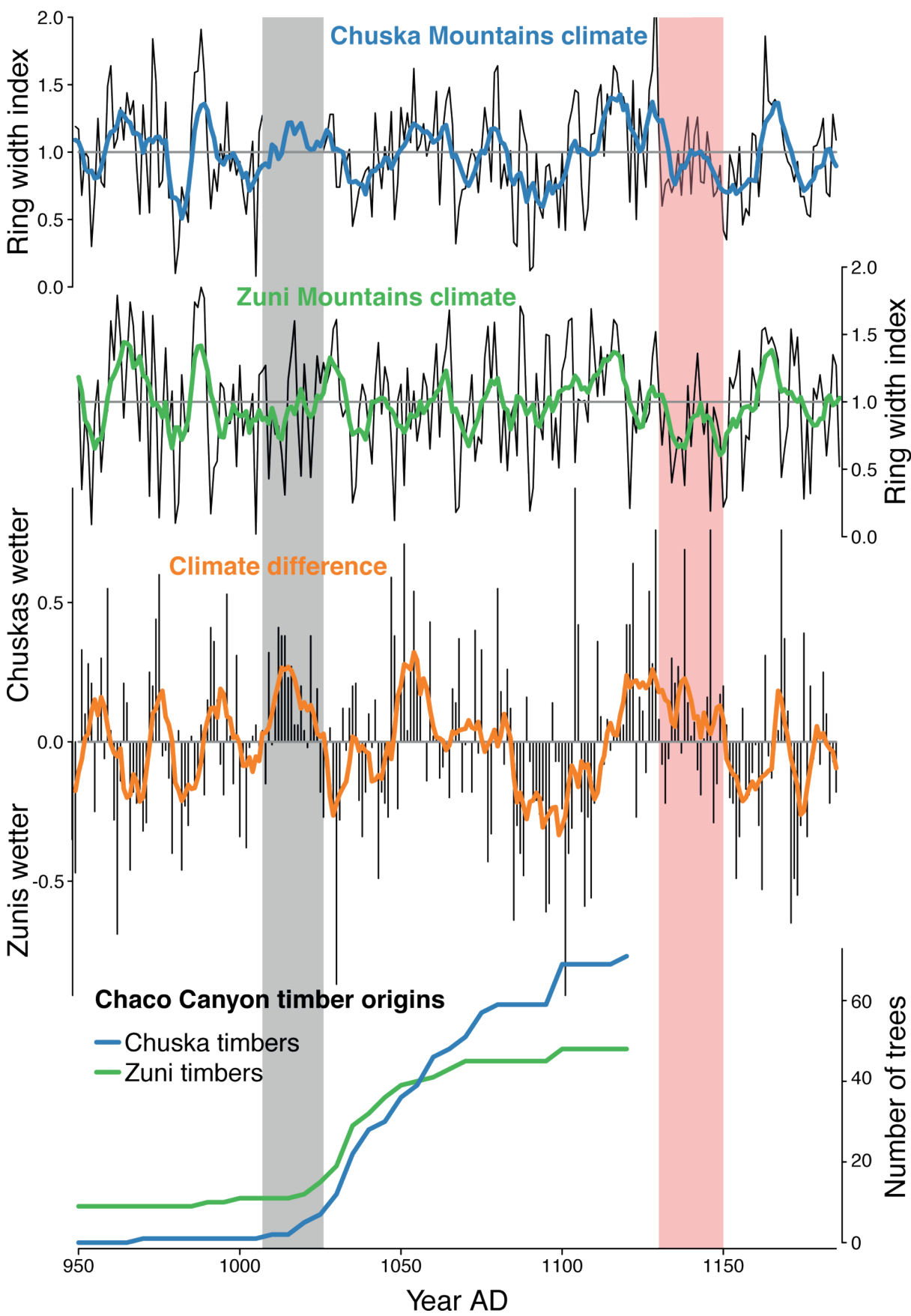

Figure 2: Local climates and timber extraction. Precipitation-sensitive tree-ring-width chronologies from the Chuska and Zuni Mountains show sub-regional differences in the timing, duration and severity of drought. One period (AD 1007-1026; grey shading) coincides with the arrival of Chuska timbers to Chaco Canyon. The 12th century megadrought (AD 1130-1150; red shading) probably initiated collapse at Chaco and was longer and deeper in the Chuskas than the Zunis. Bold lines in the top three panels are seven-year running averages. The third panel shows the difference between the Chuska and Zuni tree-ring chronologies. Data from Guiterman et al. (2016).

stands, including nearby Chacra Mesa. Ultimately, this could have reduced nearby seed sources from which local pinyon populations could regenerate.

\section{A possible role for megadrought}

Impacts of the recent 2000s drought in the region underscore a climate explanation.

Over the last two decades, severe droughts in western USA have resulted in widespread and synchronized ecological disturbances, including wildfires, pine beetle outbreaks, and tree die-offs (Williams et al. 2013). These events have inspired a flurry of research on the impacts of hotter drought associated with anthropogenic warming, but both archaeologists and paleoecologists, including the authors, are currently revisiting the enigmatic ecological footprints of past droughts. Could pinyon at its lower and dry limits in Chaco Canyon have been wiped out by the mid-12th century megadrought? Occurring during the height of the unusually dry Medieval Climate Anomaly (MCA; AD 9001300), the mid-12th century megadrought far exceeded the severity, duration and extent of subsequent droughts (Woodhouse et al. 2010). Although ecological impacts are less well-documented, we do know that this, and other MCA droughts, synchronized extensive wildfires from California (Swetnam et al. 2009) to Colorado (Calder et al. 2015). It is likely that these droughts also produced widespread tree die-offs. As part of an ongoing study to assess past ecological disturbances in the Chuska Mountains, one of us (CHG; unpublished data) sampled over 1000 trees and found only eight that were established before AD 1150, with just three trees surviving the mid-12th century megadrought, which was apparently more severe in the Chuskas than in the Zuni Mountains to the south (Fig. 2).

\section{Future questions}

Did impacts of the extended mid-12th century drought in the Chuskas have a cascading effect on the Chaco Core and its regional system? Was the shift in sources of architectural timber from the Zuni to the Chuska Mountains around AD 1020 driven by asynchroneity in hydroclimate variability across the region, perhaps related to shifting epicenters of droughts and pluvials? Did sub-regional syn- and asynchroneities in climate and ecosystems, perhaps changing over time, determine Ancestral Puebloan movements initially to Chaco and later to other sites during abandonment? This is precisely the modeling approach taken by Bocinsky and Kohler (2014) in using tree-ring data to model the rain-fed, maize agricultural niche across the US Southwest. The same could be done for other essential resources, which could have shifted dramatically with large and synchronized disturbances driven by drought. Although Chaco Canyon has been well studied, most of the excavations and the published literature happened in the 20th century. The prospects for new research at the intersection of human impacts and climate change are not only exciting but in order.

\section{AFFILIATIONS}

'US Geological Survey, Reston, USA

Laboratory of Tree-Ring Research, University of Arizona, Tucson, USA

\section{CONTACT}

Julio L. Betancourt: jlbetanc@usgs.gov

REFERENCES

Betancourt J et al. (1986) American Antiquity 51: 370-375 Betancourt J, Van Devender T (1981) Science 214: 656-658

Bocinsky R, Kohler T (2014) Nature Comm 5, doi:10.1038/ ncomms 6618

Calder W et al. (2015) PNAS 112: 13261-13266

Diamond J (2005) Collapse: How Societies Choose to Fail or Succeed, Penguin Books, 571 pp

English N et al. (2001) PNAS 98: 11891-11896

Fernández-Armesto F (2001) Civilizations: culture, ambition, and the transformation of nature, The Free Press, $560 \mathrm{pp}$

Grimstead D et al. (2016) Geoarchaeology, doi: 10.1002/ gea. 21545

Guiterman C et al. (2016) PNAS 113: 1186-1190

Minnis P (2015) In: Heitman C, Plog S (Eds) Chaco Revisited: New Research on the Prehistory of Chaco Canyon, New Mexico. University of Arizona Press, 305-321

Plog S, Heitman C (2010) PNAS 107: 19619-19626 Samuels M, Betancourt J (1982) Environ Manage 6: 505-515

Swetnam T et al. (2009) Fire Ecol 5: 120-150

Williams P et al. (2013) Nature Clim Change 3: 292-297

Woodhouse C et al. (2010) PNAS 107: 21283-21288 